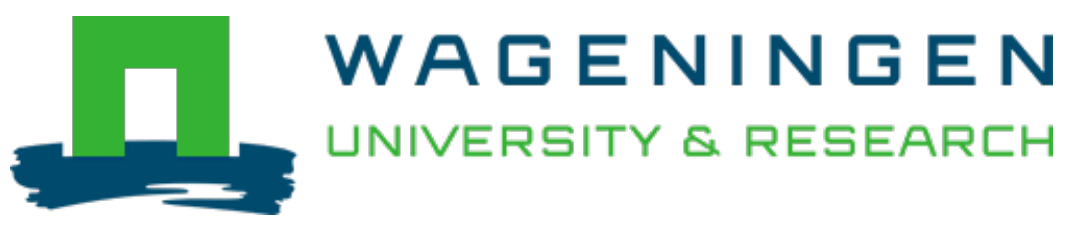

\title{
Differentiating CSR managers roles and competencies: taking conflicts as starting point
}

Research Handbook of Responsible Management

Wesselink, R.; Osagie, E.R.

https://doi.org/10.4337/9781788971966.00044

This article is made publicly available in the institutional repository of Wageningen University and Research, under the terms of article $25 \mathrm{fa}$ of the Dutch Copyright Act, also known as the Amendment Taverne. This has been done with explicit consent by the author.

Article 25 fa states that the author of a short scientific work funded either wholly or partially by Dutch public funds is entitled to make that work publicly available for no consideration following a reasonable period of time after the work was first published, provided that clear reference is made to the source of the first publication of the work.

This publication is distributed under The Association of Universities in the Netherlands (VSNU) 'Article $25 \mathrm{fa}$ implementation' project. In this project research outputs of researchers employed by Dutch Universities that comply with the legal requirements of Article $25 \mathrm{fa}$ of the Dutch Copyright Act are distributed online and free of cost or other barriers in institutional repositories. Research outputs are distributed six months after their first online publication in the original published version and with proper attribution to the source of the original publication.

You are permitted to download and use the publication for personal purposes. All rights remain with the author(s) and / or copyright owner(s) of this work. Any use of the publication or parts of it other than authorised under article $25 \mathrm{fa}$ of the Dutch Copyright act is prohibited. Wageningen University \& Research and the author(s) of this publication shall not be held responsible or liable for any damages resulting from your (re)use of this publication.

For questions regarding the public availability of this article please contact openscience.library@,wur.nl 


\section{Differentiating CSR managers' roles and competencies: taking conflicts as a starting point}

Renate Wesselink and Eghe R. Osagie

\section{INTRODUCTION}

Companies increasingly acknowledge the importance of responsible management to tackle sustainability challenges. Although there is no clear and undisputed definition of responsible management (RM), there are specific topics that are often included in research on RM (Nonet et al., 2016). These topics can be categorized in three domains: the domain of sustainability/ corporate social responsibility (CSR), the domain of stakeholder value, and the domain of ethics (Laasch \& Conaway, 2015). In this chapter we focus on the first, the domain of CSR. CSR consists of "context-specific organizational actions and policies that take into account stakeholders' expectations and the triple bottom line of economic, social, and environmental performance" (Aguinis, 2011: 855) or as more simply put by Van Marrewijk and Werre (2003) the business strategy for realizing sustainability.

Socially responsible behaviour should be developed in and acted upon by both employees and management to ensure it is integrated into company's DNA (Verkerk et al., 2001). RM focuses on the role of mainstream managers to bring about this change. It acknowledges that business practices are steered by decisions made by influential individuals within the company. Integrating sustainability, responsibility and ethics in mainstream managers' daily practice would eventually lead to more responsible employees, teams, and companies (Laasch, 2018a). Whereas this focus on individual level influencers are in abundance in RM research, this level of analysis has long time been neglected in CSR research where the vast majority of the research focuses on strategic or corporate level drivers of CSR (Aguinis \& Glavas, 2012). In this chapter, therefore, the focus is not only on the individual level, but it also addresses a particular group of managers, namely the CSR managers whose main job is to work on CSR implementation (Laasch \& Conaway, 2015). CSR managers differ from mainstream managers; they are the chosen few who are specifically employed to implement CSR (Osagie et al., 2019), and are thus specialized responsible managers, whereas mainstream managers are many and have general managerial tasks. However, despite these differences, the two functions also overlap in tasks and may complement each other. In fact, it is likely that in the future these two types of managers will merge, as more mainstream managers might integrate CSR in their daily tasks. As such, insights provided in this chapter will be relevant and applicable to the field of responsible management to a great extent.

According to Aguinis and Glavas (2012) CSR managers are those individual actors who actually strategize, make decisions, manage and sometimes execute CSR practices. These managers operate either inside corporate borders being responsible for the implementation of CSR or outside corporate borders as consultants. They are growing in number and importance; sustainability has recently ascended the corporate ladder towards the top managerial levels as the number of executive positions in the sustainability area is increasing (Carollo \& Guerci, 
2018; Knight \& Paterson, 2018). These CSR managers must deal with many uncertainties and must work extensively with external stakeholders due to the complex nature of sustainability challenges (Dentoni et al., 2012). Moreover, they often work in environments in which little support is available for CSR or in which employees are ambivalent towards the proposed changes, because the beneficial effects of CSR for the business are often not directly observable in the short run, for example (Heiskanen et al., 2016). As such, the CSR managers' position is a challenging position, and many CSR managers experience conflicts (Hahn et al., 2014). These conflicts often occur because CSR managers are strongly emotionally invested with CSR and as such are socially and ethically driven in their work behaviour. Yet, they frequently work in companies that have their own prevailing company approach or values, one that is often dominated by profit orientations or cost-efficiency. In fact, CSR managers' position is produced exactly because of these conflicts, which they need to negotiate and tackle when managing themselves and others (Wright et al., 2012). However, these conflicts can cause internal dissonance, which can lead to a diminished work ability and even burnout among CSR managers.

Strikingly, despite the (growing) importance of CSR managers for CSR implementation, little is known about what CSR managers need to handle the conflicts resulting from the search for both profit and CSR (Ghadiri et al., 2015). Therefore, in this chapter we will address these conflicts explicitly. We will synthesize the literature with regard to these conflicts and the roles and competencies employed by CSR managers. We address these issues not solely from the viewpoint of the CSR manager, but also from the business context these CSR managers operate in; a context in which different values have to be taken into account and value conflicts occur from. The chapter concludes by stressing the need for a reconsideration on the existing lists of CSR managers' job roles and competencies.

\section{APPROACH OF THIS CHAPTER}

CSR is studied in many different disciplinary fields such as strategy (Porter \& Kramer, 2006), management (Maon et al., 2010), organisational behaviour (Aguinis \& Glavas, 2012) and marketing and communication (Kotler \& Lee, 2005) and consequently, a large number of topics are related, or potentially related, to CSR and CSR managers' (logic) conflicts. To cover this widespread field some choices are made, which will be explained here.

First, the choice was made to focus solely on businesses. We mean to identify CSR managers' logic conflicts, which are most apparent in businesses for profit where it has been shown to affect CSR managers' actions and behaviour (Osagie et al., 2019). Second, the choice was made to limit the search to empirical studies in peer-reviewed articles traceable in scientific databases (using Scopus and Web of Science) that explicitly used the terms responsible/ sustainable/CSR managers/specialists/related roles/consultants/leadership, corporate social responsibility (CSR), corporate sustainability or sustainability and struggles/dilemma's/tensions/job strain/challenges/work stress. Here we used the definition of conflict as provided by Carollo and Guerci (2018); a conflict exists when elements that seem logical individually but when taken together are inconsistent or even absurd when juxtaposed. The same list of key words was used in combination with competencies/skills/qualities. Next, as the current review of the literature is meant to explore and provide a narrative of the conflicts experienced by CSR manager, rather than aiming for completeness, we focus our search on empirical studies 
that provide rich information on this topic. As such, in addition to the initial search, we applied a snowballing method to find additional relevant articles.

The search for relevant articles showed that they were published in the last five to seven years. In early 2012 relevant articles dealt with the topics of leadership (mostly dealing with the CEO, for example, of companies) and increasingly the CSR managers were studied as companies' change agents. Similar findings were presented in the systematic review of Aguinis and Glavas (2012); they found that of the total number of CSR journal articles encompassing the individual level of analysis, about 50 per cent have been published since 2010 . Moreover, our search also confirmed the multidisciplinary character of the CSR research field. Journals publishing relevant articles range from sustainability-oriented journals such as Ecology and Society, management-oriented journals like Organization Studies and Journal of Organisational Change Management, to journals from the Communication and Human Relations discipline and journals at the crossroads of two disciplines such as Journal of Business Ethics.

In the remainder of this chapter we will present a narrative of the conflicts experienced by CSR managers, using the results found in our literature review. Finally, existing lists of job roles and competencies for CSR managers are reconsidered in light of the conflicts experienced by CSR managers.

\section{CONFLICTS EXPERIENCED BY CSR MANAGERS}

The article by Carollo and Guerci (2018) on CSR managers' conflicts is used as a starting point for the review on conflicts and is complemented by additional conflicts identified by other scholars. Carollo and Guerci (2018) identified three conflicts (which they call tensions, and are in this chapter considered as equivalents). The first conflict deals with the dilemma between business orientation vs. value orientation (Carollo \& Guerci, 2018). At one pole there is a dominant view of managerial work as oriented to profit maximization and financial performance. At the other pole the work of the CSR managers is interpreted as a mission in which they want to create value for the society and environment. Within specific practices the two views coincide. However, most often each practice does require different decisions and practices.

The second conflict concerns the dilemma between the organisational insider vs. outsider (Carollo \& Guerci, 2018). As an organizational insider the CSR manager is in a position close to the top management, and considers him- or herself as a full organizational member and constructs his or her (work) identity accordingly. Within the role of the 'organizational outsider' the CSR manager internalizes an external view on the company's CSR issues. Wright et al. (2012) illustrate this 'outsider perspective' as follows: 'green' change agents - those CSR-related professionals who have the profession to advice their/other organizations how to improve their CSR practices - are sometimes labelled by other organisational members as 'hippies' or 'tolerated eccentrics' because they stand outside the existing organisational norms. CSR managers may feel torn between the two roles when their company's internal logics are not aligned with the interest and demands of external stakeholders (p. 1462). Although they often are both the insider and the outsider, this conflict may distort their work identity.

The third conflict concerns the short term vs. long term (Carollo \& Guerci, 2018). Short-term focused CSR managers feel the need to pursue immediate results as a reaction to 
pressing CSR issues. Long-term focused CSR managers are aware of the long-term horizon typical for CSR. CSR managers should be able to face the contingencies that emerge in their day-to-day work while simultaneously keeping an eye on long-term trends and planning for future changes. Those who have the attitude of a patient believer, and wait for the organization to change (in the role of mediator) will experience a delay with incorporating the pressures exerted by the organizational environment. In short, the context in which a CSR manager is acting, is obviously important in making a choice between these two foci.

The fourth conflict regards a conflict between local CSR policy and global CSR policy (Acquier et al., 2018). This conflict is particularly experienced by CSR managers in Multi-National Companies (MNC). These CSR managers have to serve at both local and a global level. It can be challenging for them to develop a CSR policy that is relevant at both levels. That is, what seems essential at the global level (e.g. water scarcity) may be less pressing at the local level where (clean) water seems to be in abundance.

The fifth conflict deals with implicit vs. explicit CSR. According to Matten and Moon (2008) CSR practices can be divided into two competing approaches that depends on the level of institutional influences. Within the implicit CSR approach, CSR practices are driven by 'values, norms, and rules, that results in (mandatory and customary) requirements for corporations to address stakeholder issues' (Matten \& Moon, 2008: 409; e.g. inside-out approach by Nijhof et al., 2008). These companies view CSR as an implicit part of their institutional framework, and do not communcitate and label their CSR practices seperately from their business practices. Within the explicit CSR approach, CSR practices are the result of deliberate and often strategic decisions made by the company (e.g. outside-in approach, Nijhof et al., 2008). These companies explicitly communicate about their CSR practices, often separately from other business practices (Matten \& Moon, 2008). Using these two approaches Angus-Leppan et al. (2010) studied CSR managers in a case study and discovered that implicit CSR was mainly driven by authentic and emergent leadership and explicit CSR was driven by autocratic leadership. Having these two approaches at the same time may lead to conflicts as it can be seen as greenwashing and lead to conflicting CSR practices (e.g. not talking about CSR explicitly but rather about values, yet at the same time striving to be number one on the Dow Jones Sustainability Index).

The sixth and final conflict concerns emotional conflicts and the regulation thereof. CSR managers have to deal with emotional dissonance as their behaviour and public displays of emotion can differ strongly from their own beliefs. Take for example climate change. Some decision makers within the company may not believe or support the idea of global warming and/or climate change, whilst a CSR manager is convinced of this. Dealing with the difference in beliefs and the decisions made by these stakeholders can be detrimental for CSR managers (Wright et al., 2012).

Notwithstanding the importance of separate conflicts, in general, these conflicts reflect situations where there is a tension between a profit- and social value orientation, and as such can be positioned on the profit creation versus social value creation continuum (see Figure 34.1). For example, in contrast to short-term CSR, long-term CSR obligations or commitments are often less attractive businesswise and can be placed on the right pole of the continuum. This is because their beneficial effects are often not (directly) observable on the short term, are not always financial, and are accompanied with many uncertainties, which makes it difficult for businesses to commit to. Similarly, implicit and explicit CSR approaches can also be positioned on this continuum. With an explicit CSR approach companies are transparent on 
the (financial) gains of their CSR efforts (e.g. the energy and financial savings due to use of solar panels). Whilst with an implicit CSR approach, agreements are made for the longer term and performance indicators are predominantly not in terms of financial gains (i.e. social value creation).

The profit creation versus social value creation continuum described here originates from conflicts experienced by CSR managers. However, the distinction between different value frames has been addressed in previous work, based on strategic management theories or institutional theories (Ocasio \& Radoynovska, 2016). Based on theories about institutional logics (e.g. Thornton et al., 2012), Laasch (2018b) identified a similar divide. He distinguishes the logic of organisational value of the commercial market from the logic of sustainable development. The commercial market approach is dominated by the market logic, which means dominated by financial value creation and shareholder-driven profit maximization. The sustainable development logic was originally not identified as one of the institutional logics as developed by Thornton et al. (2012); however, it was added later by scholars such as Laasch (2018b) and Randles and Laasch (2016) due to the growing attention for sustainability. Accommodating different logics in general and these two in particular can end up in either institutional pluralism or complexity (Ocasio \& Radoynovska, 2016). Pluralism suggests that there exists a multiplicity of institutional logics and these logics co-exist in organisations. There are hardly any tensions or conflicts and oftentimes it even leads to heterogeneity in business models (Laasch, 2018b). They are sometimes even regarded as productive tensions. Having different logics in an organisation or in its environment might lead to institutional complexity, in which complexity implies the experience of incompatibility and tensions between two or more logics (Ocasio \& Radoynovska, 2016).

With regard to sustainability or CSR, in many cases both poles may turn out to be compatible (institutional pluralism), which can lead to an improved (sustainable) business model. However, when stakeholders put other logics to the front or stakeholders with other logics enter the arena, the balance might be disrupted. In that case one talks about complexity. Within this institutional complexity an organisation will search for a new balance (i.e. pluralism), periods in which the role of the CSR manager (i.e. change agent as identified by Ocasio \& Radoynovska, 2016) becomes particularly relevant; they are in the lead of redefining the business model to align it with the newly emerging demands, constraints and ambitions. Thus, juggling the different logics at stake in times of transformation is per definition the playing field of CSR managers. However, to what extent are CSR managers equipped to work on these transformations? The next paragraph shows the job roles and individual competencies necessary in the CSR manager function.

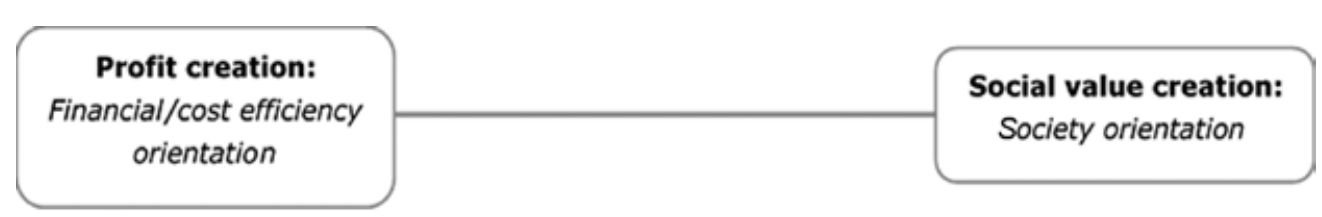

Figure 34.1 The profit creation vs. social value creation continuum 


\section{CSR ROLES AND COMPETENCIES}

Individual competencies can be perceived as a person's integrated performance-oriented ability to achieve specific objectives, meaning that in practice it is difficult to isolate specific competencies (Mulder, 2014). Interestingly, most lists of CSR managers' competencies are not or only to some extent connected with the context or its objectives (Osagie et al., 2019). Laasch and Moosmayer (2016) also stress the relevance of connecting competencies to distinct contexts. Osagie et al. (2019) and Wesselink et al. (2015) made a first attempt to contextualize CSR competencies, by relating them to specific job roles. Here we expand on this first attempt and relate the competencies and job roles to the profit creation versus social value creation continuum. With this theoretical exercise we seek to show why it is important to interpret existing lists of CSR competencies and job roles within the organizational context CSR managers operate in. To see whether we can detect contextual differences in job roles and competencies, we will position existing CSR job roles and competencies at either one of the poles. Based on this analysis, we will then answer the following question: To what extent can existing lists of CSR managers' roles and competencies be brought to a next level by taking conflicts as a starting point?

\section{CONNECTING THE POLES TO ROLES AND COMPETENCIES}

A first salient result of the literature review is that scholars seem to agree to a large extent on the roles CSR managers have in their job (e.g. Carollo \& Guerci, 2017; Knight \& Paterson, 2018; Osagie et al., 2019). Though they use different labels to address these roles, the content and described tasks in these roles are rather similar, as will be shown below. The starting point for the inventory of relevant roles and competencies for the profit creation-pole, is the work done by Osagie et al. (2019). These authors first identified, based on a systematic literature review, relevant competencies for CSR managers (Osagie et al., 2014). Next, they identified relevant job roles for CSR managers and empirically selected the three most important competencies for each role. We realize that after 2014 probably new lists with competencies and roles were developed; however, we take the lists developed by Osagie et al. (2014 and 2019) as a starting point, because they are grounded in both theory and the business practice. If applicable we complement the work done by Osagie and colleagues (2019) with other studies that have both empirical and theoretical strong foundations. First, we analyse which roles are relevant for each pole, as roles are considered to be the closest link to practice; next, this step is complemented with competencies.

\section{Profit Creation-Oriented Roles}

Three out of the six roles of Osagie et al. (2019) are explicitly geared towards the profit creation-pole of the continuum. These roles are coordination role, strategic role and monitoring role. The core of the coordination role is supporting the business units during the CSR implementation process, whilst leaving the actual responsibility in their hands. CSR managers provide support when necessary and are normally in charge of monitoring the progress (i.e. monitoring role). Whereas the coordinating role deals with the units in the organization, the strategic role mainly focuses on CSR strategy development and integrating 
the CSR strategy into the business strategy by means of formulating the business case. Within a business context, these three roles focus on integrating CSR into existing processes with a profit-oriented/cost-efficient strategy.

Independently but around the same time as Osagie et al. (2019), Carollo and Guerci (2017) developed, from an organisational change management perspective, a list of five roles. Three of them particularly represent the business side of CSR. Within the motor of change role the CSR manager is the change agent and is responsible for making the change happen, no matter what change (i.e. coordinating role in Osagie et al., 2019). Within the bookkeeper role the CSR manager is responsible for reporting (i.e. monitoring role in Osagie et al., 2019). Lastly, as the business-oriented CSR manager (i.e. strategic role in Osagie et al., 2019), the CSR manager perceives CSR as a source of competitive advantage, making the business case for CSR the dominant driver for engaging in CSR practices.

Taking an 'identity' perspective, Wright et al. (2012) describe similar roles for CSR-related professionals. In their article with the appealing title: "Hippies on the third floor" they investigate the interaction between identities (of CSR managers) and how organizations respond to climate change. They identified three identities of which one fits the profit creation-pole of the continuum: rational manager. In this role a CSR manager operates in the best interests of his or her organisation, which is often related to discourse of efficiency, profitability and shareholder value. We position the other two on the social value creation pole of the continuum, which we will elaborate on in the next paragraph.

Knight and Paterson (2018) describe their roles in terms of five clusters, each containing 10 prominent and 10 critical behaviours (i.e. competencies) for sustainable leaders. The five clusters are: (1) results driven, (2) inclusive operator, (3) change agent, (4) ethically oriented, and (5) visionary thinker. The results driven- (action focused) and change agent role (coordinating and monitoring tasks) resemble the aforementioned profit-creation roles. Less obvious, but also on this pole, is the role of the visionary thinker; because of its emphasis on the strategy and future goals it closely resembles the strategic role described in Osagie et al. (2019). The other two roles are considered important on the other pole.

In short, on the profit creation-pole of the continuum, there are great similarities in the different lists of job roles for CSR managers. While Osagie et al. (2019) use a general but often employed labelling of managerial job roles (i.e. Quinn, 1988), others like Carollo and Guerci (2017) have their origin in change management. Therefore, the general labelling used by Osagie et al. (2019), particularly the strategic and coordinating role, can be developed further by using the more meaningful labels of respectively 'business-oriented role' (Carollo $\&$ Guerci, 2017) and 'change agent role' (Wright et al., 2012).

\section{Profit Creation-Oriented Competencies}

To effectively perform the aforementioned roles, CSR managers need individual competencies. In this section, we describe relevant competencies for each role. Two recent studies specifically connect relevant competencies to job roles of (CSR) managers, namely Knight and Paterson (2018) and Osagie et al. (2019). Table 34.1 provides an overview of the competencies in relation to the change agent role, business-oriented role and monitor role.

Table 34.1 shows to some extent agreement between Osagie et al. (2019) and Knight and Paterson (2018) on the individual competencies for the change agent, the business-oriented role and the monitoring role. In particular, understanding the internal and external systems 


\section{Table $34.1 \quad$ Relevant competencies at the profit-creation side of the continuum}

\begin{tabular}{|c|c|c|c|}
\hline Competencies* & $\begin{array}{c}\text { Change agent } \\
\text { role }\end{array}$ & $\begin{array}{c}\text { Business } \\
\text { oriented role }\end{array}$ & Monitoring role \\
\hline C1. Managing CSR implementation & $\mathrm{X} 0$ & & \\
\hline C2. Realizing CSR supportive interpersonal processes & X0 & & \\
\hline C3. Anticipating CSR related challenges & $\mathrm{X} 0$ & $\mathrm{X} 0$ & \\
\hline C4. Understanding CSR relevant systems & $\mathrm{X}$ & $\mathrm{X} 0$ & $\mathrm{X} 0$ \\
\hline C5. Realizing self-regulated CSR related behaviours and active involvement & $\mathrm{X} 0$ & & $\mathrm{X} 0$ \\
\hline C6. Understanding CSR relevant standards & $\mathrm{X}$ & & $\mathrm{X} 0$ \\
\hline C7. CSR leadership competencies & 0 & $\mathrm{X} 0$ & \\
\hline C8. Identifying and realizing CSR related business opportunities & 0 & $\mathrm{X} 0$ & \\
\hline C9. Balancing personal ethical values and business objectives & 0 & $\mathrm{X} 0$ & $\mathrm{X}$ \\
\hline C10. Ethical normative competence & & $\mathrm{X}$ & $\mathrm{X}$ \\
\hline C11. Reflecting on personal CSR views and experiences & & & X0 \\
\hline
\end{tabular}

Notes: $*=$ the full descriptions of the competencies can be found in Osagie et al. (2014). X= derived from Osagie et al. (2019). 0=derived from Knight and Paterson (2018).

involved (C4) seems most important, which highlights the organizational-wide change that is needed in implementing CSR and the complex nature of CSR challenges. Interestingly, both Knight and Paterson (2018) and Osagie et al. (2019) stress the importance of the combination of profit creation competencies and (personal) value-focused competencies (see Table 34.1, C9, C10, and C11) for the profit creation roles, though Osagie et al. (2019) seem to provide more evidence for the value-oriented competencies; on the one hand CSR managers need to closely align with exiting business practices and language (e.g. articulating information or developing strategies); on the other hand they have to deal with resistance, barriers and set backs on a personal level to make the change happen (e.g. recovering from set-backs and projecting cheerfulness). The personal value-focused competencies at this side of the continuum mainly have to deal with dealing with resistance and how to arm oneself for setbacks.

\section{Social Value Creation-Oriented Roles}

Based on the literature (Osagie et al., 2019; Carollo \& Guerci, 2017; Wright et al., 2012 and Knight \& Paterson, 2018) a list of roles is compiled which represents the social value creation pole of the continuum. Using Osagie et al. (2019) to start with, the three remaining roles were identified, namely the stimulating role, networking role and mentoring role. Within the stimulating role CSR managers act as ambassadors of CSR; their personal ideas and way of living are based on sustainability ideals. CSR managers employ these ideals, authenticity, and engaging attitude in activating others to engage in social behaviour. In the networking role, CSR managers represent their company and their profession outside the company. They seek and maintain contact with external parties, and learn from their peers (Osagie et al., 2018). The third role on this pole is the mentoring role. In this role, CSR managers advise, inform and train other employees, so they are better equipped to integrate CSR in their daily practice.

Carollo and Guerci's (2017) ideas on the fatalist role and the idealist role of CSR managers provide additional insights into what Osagie et al. (2019) labelled the 'stimulating role'. Within the idealistic role the CSR manager is a heroic idealist who actively fights to promote a social value-oriented vision in organisations. Within the fatalist role, on the other hand, CSR 
managers have a strong faith in the future of CSR; however, they see that there is still a long way to go, which 'cripples' them and makes them reactive instead of proactive. CSR managers applying this role do share the CSR ideals; however, they are hesitant in achieving these ideals actively due to their company's profit-orientation and choose to wait (Carollo \& Guerci, 2017). It follows that the idealistic role fits the social value creation pole in the best way. This idealistic role of CSR managers is strengthened by the descriptions of Wright et al. (2012) of the green change agent and the committed activist; both are positioned at the social value creation pole. According to Wright et al. (2012) CSR managers have CSR ideals as a starting point for their work behaviour (and personal livelihood), no matter the resistance experienced. Finally, the set of roles by Knight and Paterson (2018) include two more roles: the inclusive operator which focuses on dealing with others, by means of understanding, collaboration and trust and an ethically oriented role which emphasizes that people act with integrity and have an ethical approach in their work practices. The latter describes the social value creation pole even to a further extent.

To summarize, the literature describes the idealistic role as most important within the social value creation pole. The only role that seems to reflect the social value creation pole to its fullest extent is the 'stimulating role' or the 'idealistic role'. In this role, CSR principles are the starting point, whilst in the other roles, the process is more apparent instead; mentoring can serve either one of the poles, some holds for networking.

\section{Social Value Creation Competencies}

Based on the sources mentioned in the section above, a set of competencies relevant for the idealistic role is composed. All competencies as identified by Osagie et al. (2019) are again taken as the starting point. This list is complemented with the competencies as identified by Knight and Paterson (2018) in two specific roles in which they provide a more in-depth look at the social value-oriented competencies needed in the idealistic role. They identified for the two roles the following competencies (between brackets the relation with the competencies of Osagie et al., 2019):

- Inclusive operator:

- building trust-based relationships (C2)

- $\quad$ showing consideration and tolerance for the beliefs and world-view of others (C10)

- the need to have empathy, listen well and comprehend others' motivations (C2)

- being able to collaborate and involve others in decision making (C2)

- Ethically oriented:

- $\quad$ networking and stakeholder management (C2 \& C7)

- the ability to project inner strength and leave ego at the door (C5)

- $\quad$ standards and empowering individuals (C11).

Next to Osagie et al. (2019) and Knight and Paterson (2018), the list of CSR-related competencies of Brown (2012) is compared with the current set of competencies. Although Brown's list of competencies did not explicitly connect the competencies to job roles, it describes the competencies of leaders with so-called post-conventional consciousness (and not being in the pre-conventional or conventional stage), in which post-conventional meaning making means that someone's focus is on the whole system and the roles in the system and one's eagerness to change the system. It focuses on the self in relationship to the system and interaction with the 
system, linking theory and principles with practice and focuses on the interplay of awareness, thought, action, and effects transforming self and others. This consciousness fits the social value creation pole to a great extent. Brown (2012) compiled a list of 15 competencies, which are again compared with the competencies of Osagie et al. (2019):

- Ground sustainability practice in deep (spiritual/sacred) meaning (C10 \& C11)

- Intuitive decision-making and harvesting other than rational analysis (C5)

- Embrace uncertainty with profound trust (C5)

- Scan and engage the internal environment (C2 \& C11)

- Inhabit multiple perspectives (C4)

- Dialogue with the system (C2)

- Go with the energy (C5)

- Self-transformation (C11)

- Create development conditions (C2 \& C7)

- Create and hold appropriate space to stimulate the group process (C2 \& C5)

- Shadow mentoring (C2)

- Systems theory and systems thinking (C4)

- Complexity theory and complexity thinking (C3 \& C4)

- Integral theory and integral thinking (C4)

- Polarity management (C2).

Table 34.2 shows the competencies that are deemed most important for the idealistic role (i.e. stimulating role) and summarizing the studies mentioned in relation to this pole. These competencies represent the idealist role and therefore the social value creation pole to the full extent without any compromises to the profit creation side of the continuum. Having a closer look at the competencies, again the interpersonal competencies are emphasized strongly. However, looking at these competencies, the system as such is not seen as a given. The CSR manager has a dialogue with the system, which means that the system as such is also the object of change and that companies and their CSR managers could accelerate that change. This finding is of particular interest for CSR managers working in companies where social value creation is the starting point and in which they dare to question and change the existing system.

Table 34.2 shows that literature provides most evidence for ethical normative competence (C10) and the interpersonal competencies (C2) as relevant for the idealistic role. It shows the ethical starting point in this role, as well as the need for CSR managers to distribute ownership of CSR and leadership across the company.

Furthermore, Table 34.2 demonstrates that even within the idealistic role, business case-oriented competencies, are still deemed important (Knight \& Paterson, 2018; Osagie et al., 2019). That is, the business case arguments for engaging in CSR are still in place and remain influential for CSR managers' work behaviour even on the social value creation pole of the continuum. The latter was especially evident in the research of Osagie et al. (2019), but far less in Brown's (2012) study on meaning-making of CSR leaders working on CSR initiatives.

\section{CONCLUSION AND DISCUSSION}

In this chapter, by means of a literature review we explored conflicts CSR managers experience in their jobs and investigated to what extent these conflicts suggest differentiation in the 
Table 34.2 Relevant competencies at the social value creation pole of the continuum

\begin{tabular}{|c|c|c|c|}
\hline \multirow[t]{2}{*}{ Competencies* } & \multicolumn{3}{|c|}{ Idealistic role } \\
\hline & $\begin{array}{l}\text { Osagie et al. } \\
\qquad(2019)\end{array}$ & $\begin{array}{c}\text { Knight \& } \\
\text { Paterson } \\
(2018)\end{array}$ & $\begin{array}{l}\text { Brown } \\
(2012)\end{array}$ \\
\hline \multicolumn{4}{|l|}{ C1. Managing CSR implementation } \\
\hline C2. Realizing CSR supportive interpersonal processes & $\mathrm{X}$ & $\mathrm{X}$ & $\mathrm{X}$ \\
\hline C3. Anticipating CSR related challenges & $\mathrm{X}$ & & \\
\hline \multicolumn{4}{|l|}{ C4. Understanding CSR relevant systems } \\
\hline $\begin{array}{l}\text { C5. Realizing self-regulated CSR related behaviours and } \\
\text { active involvement }\end{array}$ & & & $\mathrm{X}$ \\
\hline C6. Understanding CSR relevant standards & & & \\
\hline C7. CSR leadership competencies & $\mathrm{X}$ & & $\mathrm{X}$ \\
\hline $\begin{array}{l}\text { C8. Identifying and realizing CSR related business } \\
\text { opportunities }\end{array}$ & $\mathrm{X}$ & & \\
\hline $\begin{array}{l}\text { C9. Balancing personal ethical values and business } \\
\text { objectives }\end{array}$ & $\mathrm{X}$ & $\mathrm{X}$ & \\
\hline C10. Ethical normative competence & $\mathrm{X}$ & $\mathrm{X}$ & $\mathrm{X}$ \\
\hline C11. Reflecting on personal CSR views and experiences & & $\mathrm{X}$ & $\mathrm{X}$ \\
\hline
\end{tabular}

Note: $*=$ the full descriptions of the competencies can be found in Osagie et al. (2014).

existing lists of CSR managers' roles and competencies. This exploration of literature provides us with some insights. First, CSR managers experience conflicting situations resulting from tensions between profit creation- and social value creation logics. This conflict does not only occur at the level of the individual, but has equivalents on organisational levels. Second, depending on both the company's logics and position on the continuum, CSR managers have different dominant job roles to fulfil and have to poses different individual competencies to drive CSR implementation. Whereas the change agent, business oriented role and monitoring role are geared towards the profit creation pole, the idealist role is especially geared towards the social value creation pole. Two roles were more difficult to position: networking and mentoring. Both could serve either pole of the continuum. Third, most important competencies on the profit creation pole are 'understanding CSR relevant systems' and 'balancing ethical values and business objectives'. At the social value creation pole especially 'interpersonal processes' and 'ethical normative competence' were strongly represented. Knowing this, we can argue that 'knowing the systems' and 'balancing values' are important qualities on the left pole and being able to 'work with others' and having a strong 'internal ethical compass' helps CSR managers on the other pole. In this sense, we found evidence that differentiation in roles and competencies is needed, depending on the position on the continuum. This finding is in line with the expectation from Laasch and Moosmayer (2016) as they stated that competence profiles should be drafted for distinct contexts. In this chapter a first attempt was made to study this claim.

As said before, having different values (or logics) does not necessarily mean there is a conflict. Different values or logics might co-exist in companies without complications. In that case we talk about a balanced situation (institutional pluralism). However, there are moments when some logics become more dominant or stakeholders come into play with different logics or values. In these cases, we talk about disruption, or as called by Ocasio and Radoynovska (2016) complexity. In these cases, conflicts become more prominent. CSR managers will 
experience these transitions and they have to act according to their personal values and have to carefully look at the dominant logics of the company and its stakeholders to move from complexity to institutional pluralism again. Transitions are not always imposed. Companies can choose to move up the ladder of CSR maturity. In these cases, CSR managers should be aware of the current status of CSR and the desired status of CSR. Van Marrewijk and Werre (2003) among others, provide a nice system of maturity levels, which could help CSR managers in their search. They talk about CSR maturity levels.

\section{CSR Maturity Levels}

Companies may have different strategies on how to deal with CSR and different ideas on the extent in which to integrate CSR in core business processes. These differences have been presented in different ways in the CSR literature. For example, Van Marrewijk and Werre (2003) distinguished six CSR maturity levels ranging from pre-CSR (no CSR practices at all), via profit-driven CSR to holistic CSR. Whilst other ways exist to categorize CSR maturity levels (see for example Lozano (2008) or Van Tulder et al. (2009)), they all closely resemble Van Marrewijk and Werre's categorization. Whereas in the pre-CSR level companies have no intentions at all with regard to CSR, within the profit-driven ambition level CSR companies integrate social, ethical, and ecological aspects of CSR into business operations and decision-making, provided there is a business case and it contributes to the financial bottom line (profit creation). Within the holistic CSR, CSR is fully integrated and embedded in every aspect of the organization and CSR is aimed at contributing to the quality and continuation of life of every being and entity, now and in the future (social value creation). The difference in company's maturity levels affects the roles and competencies CSR managers should have in their work and as such the competencies or the extent into which specific competencies are needed to effectively perform these roles (Osagie et al., 2019). For example at the profit creation-pole in which understanding the systems and balancing values are important. Within this context, where discourses focus on productivity, efficiency, and financial gains, the CSR manager should be business-oriented; this is more effective for convincing others of the merits of CSR actions than taking up the role of the idealist. In times of transformation (institutional complexity), in which there is no balance in values and logics (for a certain period of time), CSR managers can provide guidance through their networking and mentoring role. Besides, CSR managers should be able to switch between roles and competencies; they need to negotiate between their personal CSR orientation and the company's dominant logic (Wright et al., 2012). However, these are assumptions and guesses and it would be great to make in future research a distinction between balanced situations and situations of complexity.

As stated in this chapter, especially in situations of complexity, the emotions of a CSR manager can come into play and might be at risk. Wright and Nyberg (2012) stress the importance of looking at these situations from an emotional point of view. According to these authors, tackling these conflicts involves learning how to regulate one's own emotions. Wright and Nyberg (2012) identified four strategies through which CSR managers could champion conflicting situations:

- Calculative use of emotions - consciously tailor emotional expression to fit situational contingencies. For example, be rational and present a clear business case for CSR in cases were the other is sceptical and disengaged. 
- Constrain personal emotions - downplay and subdue personal passion.

- Championing their emotions - personify the CSR message by being explicit about one's emotions and passions to inspire others.

- Compartmentalizing - differentiate in emotional expression and CSR ambitions depending on the context. For example, being really passionate about CSR at home and hiding the intensity of this passion in a bottom-line focused company.

Besides the competencies and the regulations of one's personal emotions, tackling these conflicts also requires one to know oneself deeply and critically (Brown, 2012). CSR managers should position both themselves as their company on the profit creation versus social value creation continuum. Both company and CSR manager should reflect on the type of CSR manager the company needs to bring it to the next CSR maturity level (i.e. transition towards the social value creation pole) and select the best person for the CSR manager's function accordingly. For example, a CSR manager that identifies him or herself as an idealist should probably not be selected for a bottom-line focused company with hardly any CSR ambitions. A business-oriented CSR manager would be a better fit, whereas such an idealist manager would fit better a social value creation-minded company. Thus, tackling conflicting situations also involves avoiding a mismatch in orientation. Future research might focus on this interaction of these orientations and/or logics and investigate how progress in CSR can be made without too much frustration of the responsible CSR manager.

\section{Implications for Managers in General}

Although these results are particularly interesting for CSR managers (as specialized responsibility managers) working in a business context, they may also provide guidance for other responsible managers focusing on themes that, like CSR, receive little support and enthusiasm in a business context (e.g. ethics and stakeholder value). In fact, these results may even be informative for mainstream managers working in companies that aim to integrate CSR in their DNA. In these companies, CSR should ultimately be a responsibility of all employees and not only of the selected few; both management and employees should behave in a manner that is aligned with the company's CSR values and ambitions (Verkerk et al., 2001). As such, besides the CSR managers, mainstream managers will eventually need to integrate CSR in their jobs, as they play a key role in steering employees' work behaviour and because they can increase employees' commitment to achieving a company's CSR ambitions by being visible and supportive toward the intended change (Furst \& Cable, 2008). However, as the literature review focused on CSR managers suggests, more research is needed to determine the extent mainstream managers are already including CSR in their daily work and what kind of conflicts they experience and which of the abovementioned roles and competencies are crucial for their role in the CSR implementation process. Particularly because, unlike for CSR managers, for them, CSR will most likely be one responsibility of many in their job.

\section{Implications for Education and Training}

As we learned of the work from Osagie et al. (2018), CSR managers develop themselves mainly by means of sharing their experience with peers. By reflecting with peers on their own experiences and by sharing these reflections CSR managers improve their own roles 
and competencies. Results from this chapter could guide the CSR managers in what kind of questions to ask; besides asking what works and what does not, they could address questions about the current maturity of CSR, what kind of personal logics they adhere to and to what extent and what kind of conflicts they experience. Future research could assess to what extent such reflection and learning practices can help prevent internal dissonance and burnout among CSR managers. Future research should also focus on how to prepare students for dealing with these conflicts. In educational settings geared at training CSR managers, the use of serious games or other simulations might get them acquainted with, aware of and let them experience the inherent complexity of having a playing field with (in)compatible logics.

In this chapter we reconsidered existing lists of CSR job roles and competencies in light of the conflicts experienced by CSR managers and provide a more contextualized perspective on these roles and competencies. We argue that it is more effective on the organisational level and better for the CSR managers' health, to have a careful look at the context with regard to the company's dominant logic(s) when determining the most effective course of action (and therefore behaviour and competencies) to stimulate the implementation of CSR within the company.

\section{REFERENCES}

Acquier, A., Carbone, V., \& Moatti, V. (2018). "Teaching the sushi chef": Hybridization work and CSR integration in a Japanese multinational company. Journal of Business Ethics, 148(3), 625-645. doi:10 $.1007 / \mathrm{s} 10551-015-3007-4$.

Aguinis, H. (2011). Organizational responsibility: Doing good and doing well. In: Zedeck, S. (Ed.), APA handbook of industrial and organizational psychology (Vol. 3). Washington, DC: American Psychological Association, pp. 855-879.

Aguinis, H., \& Glavas, A. (2012). What we know and don't know about corporate social responsibility: A review and research agenda. Journal of Management, 38(4), 932-968. doi:10.1177/ 0149206311436079 .

Angus-Leppan, T., Metcalf, L., \& Benn, S. (2010). Leadership styles and CSR practice: An examination of sensemaking, institutional drivers and CSR leadership. Journal of Business Ethics, 93(2), 189-213. doi:10.1007/s10551-009-0221-y.

Brown, B. C. (2012). Leading complex change with post-conventional consciousness. Journal of Organizational Change Management, 25(4), 560-575. doi:10.1108/09534811211239227.

Carollo, L., \& Guerci, M. (2017). Between continuity and change: CSR managers' occupational rhetorics. Journal of Organizational Change Management, 30(4), 632-646. doi:10.1108/JOCM-05-2016 -0073 .

Carollo, L., \& Guerci, M. (2018). 'Activists in a suit': Paradoxes and metaphors in sustainability managers' identity work. Journal of Business Ethics, 148(2), 249-268. doi:10.1007/s10551-017-3582-7.

Dentoni, D., Hospes, O., \& Ross, R. B. (2012). Managing wicked problems in agribusiness: The role of multi-stakeholder engagements in value creation: Editor's Introduction. International Food and Agribusiness Management Review, 15(B), 1-12.

Furst, S. A., \& Cable, D. M. (2008). Employee resistance to organizational change: Managerial influence, tactics and leader-member exchange. Journal of Applied Psychology, 93(2), 453-462.

Ghadiri, D. P., Gond, J.-P., \& Brès, L. (2015). Identity work of corporate social responsibility consultants: Managing discursively the tensions between profit and social responsibility. Discourse \& Communication, 9(6), 593-624. doi:10.1177/1750481315600308.

Hahn, T., Preuss, L., Pinkse, J., \& Figge, F. (2014). Cognitive frames in corporate sustainability: Managerial sensemaking with paradoxical and business case frames. Academy of Management Review, 39(4), 463-487. doi:10.5465/amr.2012.0341. 
Heiskanen, E., Thidell, Å., \& Rodhe, H. (2016). Educating sustainability change agents: The importance of practical skills and experience. Journal of Cleaner Production, 123, 218-226. https://doi.org/10 .1016/j.jclepro.2015.11.063.

Knight, B., \& Paterson, F. (2018). Behavioural competencies of sustainability leaders: An empirical investigation. Journal of Organizational Change Management, 31(3), 557-580. doi:10.1108/JOCM -02-2017-0035.

Kotler, P., \& Lee, N. (2005). Best of breed: When it comes to gaining a market edge while supporting a social cause, "corporate social marketing" leads the pack. Social Marketing Quarterly, 11(3-4), 91-103. doi:10.1080/15245000500414480.

Laasch, O., \& Conaway, R. (2015). Principles of Responsible Management: Glocal Sustainability, Responsibility, and Ethics. Mason: Cengage.

Laasch, O., \& Moosmayer, D. (2016). Responsible management competences: Building a portfolio for professional competence. Academy of Management Annual Meeting Proceedings, January 2016.

Laasch, O. (2018a). Delineating and reconnecting responsible management, learning and education (RMLE): Towards a social practice perspective in the field. CRME Working Papers, 4(5), 1-28. doi: 10.13140?RG.2.2.23327.61606.

Laasch, O. (2018b). Beyond the purely commercial business model: Organizational value logics and the heterogeneity of sustainabilty business models. Longe Range Planning, 51, 158-183.

Lozano, R. (2008). Envisioning sustainability three-dimensionally. Journal of Cleaner Production, 16(17), 1838-1846.

Maon, F., Lindgreen, A., \& Swaen, V. (2010). Organizational stages and cultural phases: A critical review and a consolidative model of corporate social responsibility development. International Journal of Management Reviews, 12(1), 20-38. doi:10.1111/j.1468-2370.2009.00278.x.

Matten, D., \& Moon, J. (2008). "Implicit" and "explicit" CSR: A conceptual framework for a comparative understanding of corporate social responsibility. The Academy of Management Review, 33(2) 404-424.

Mulder, M. (2014). Conceptions of professional competence. In: Billett S., Harteis C., \& Gruber H. (Eds.), International Handbook of Research in Professional and Practice-based Learning, 107-137. Springer International Handbooks of Education. Dordrecht: Springer Dordrecht, pp. 107-137.

Nijhof, A., de Bruijn, T., \& Honders, H. (2008). Partnerships for corporate social responsibility: A review of concepts and strategic options. Management Decision, 46(1), 152-167. doi:10.1108/ 00251740810846798.

Nonet, G., Kassel, K., \& Meijs, L. (2016). Understanding responsible management: Emerging themes and variations from European business school programs. Journal of Business Ethics, 139(4), 717-736.

Ocasio, W. \& Radoynovska, N. (2016). Strategy and commitments to institutional logics: Organizational heterogeneity in business models and governance. Strategic Organization, 14(4), 287-309.

Osagie, E. R., Wesselink, R., Blok, V., Lans, T., \& Mulder, M. (2014). Individual competencies for corporate social responsibility: A literature and practice perspective. Journal of Business Ethics, 135(2), 233-252. doi:10.1007/s10551-014-2469-0.

Osagie, E. R., Wesselink, R., Blok, V., \& Mulder, M. (2019). Contextualizing individual competencies for managing the corporate social responsibility adaptation process: The apparent influence of the business case logic. Business \& Society, 58(2), 369-403.

Osagie, E. R., Wesselink, R., Runhaar, P., \& Mulder, M. (2018). Unraveling the competence development of corporate social responsibility leaders: The importance of peer learning, learning goal orientation, and learning climate. Journal of Business Ethics, 151(4): 891-906.

Porter, M. E., \& Kramer, M. R. (2006). Strategy and society: The link between competitive advantage and corporate social responsibility. Harvard Business Review, 84, 78-92.

Quinn, R. E. (1988). Beyond rational management: Mastering the Paradoxes and Competing Demands of High Performance. San Francisco, CA: Jossey-Bass.

Randles, S. \& Laasch, O. (2016). Theorising the normative business model. Organization and Environment, 29(1) 53-73.

Thornton, P .H., Ocasio W., \& Lounsbury, M. (2012). The institutional logics perspective. Oxford: Oxford University Press.

Van Marrewijk, M., \& Werre, M. (2003). Multiple levels of corporate sustainability. Journal of Business Ethics, 44(2), 107-119. 
Van Tulder, R., Van Wijk, J. \& Kolk, A. (2009). From chain liability to chain responsibility. Journal of Business Ethics, 85, 399-412.

Verkerk, M. J., De Leede, J., \& Nijhof, A. H. J. (2001). From responsible management to responsible organizations: The democratic principle of managing organizational ethics. Business and Society Review, 106(4), 353-378.

Wesselink, R., Blok, V., van Leur, S., Dentoni, D. \& Lans, T. (2015). Individual competencies for managers engaged in corporate sustainable management practices. Journal of Cleaner Production, $106,497-506$.

Wright, C., \& Nyberg, D. (2012). Working with passion: Emotionology, corporate environmentalism and climate change. Human Relations, 65(12), 1561-1587. doi:10.1177/0018726712457698.

Wright, C., Nyberg, D., \& Grant, D. (2012). "Hippies on the third floor": Climate change, narrative identity and the micro-politics of corporate environmentalism. Organization Studies, 33(11), 1451-1475. doi:10.1177/0170840612463316. 